\title{
Tracing groundwater flow and sources of organic carbon in sandstone aquifers using fluorescence properties of dissolved organic matter (DOM)
}

\author{
D.J. Lapworth*, D.C. Gooddy, A.S. Butcher, B.L. Morris
}

British Geological Survey, Maclean building, Crowmarsh Gifford, Wallingford, Oxon, OX10 8BB

*Corresponding author

E-mail address: djla@bgs.ac.uk

\begin{abstract}
The fluorescence properties of groundwaters from sites in two UK aquifers, the Penrith Sandstone of Cumbria and the Sherwood Sandstone of South Yorkshire, were investigated using excitation-emission matrix (EEM) fluorescence spectroscopy. Both aquifers are regionally important sources of public supply water and are locally impacted by anthropogenic pollution. The Penrith Sandstone site is in a rural setting while the Sherwood Sandstone site is in suburban Doncaster. Fluorescence analysis of samples from discrete sample depths in the Penrith Sandstone shows decreasing fulvic-like intensities with depth and also shows a good correlation with CFC-12, an anthropogenic groundwater tracer. Tryptophan- like fluorescence centres in the depth profile may also provide evidence of rapid routing of relatively recent applications of organic slurry along fractures. Fluorescence analysis of groundwater sampled from multi-level piezometers installed within the Sherwood Sandstone aquifer also shows regions of tryptophan-like and relatively higher fulvic-like signatures. The fluorescence intensity profile in the piezometers shows tryptophan-like peaks at depths in excess of 50 metres and mirrors the pattern exhibited by microbial species and CFCs highlighting the deep and rapid penetration of modern recharge due to rapid fracture flow. Fluorescence analysis has allowed the rapid assessment of different types and relative abundances of dissolved
\end{abstract}


organic matter (DOM), and the fingerprinting of different sources of organic carbon within the groundwater system. The tryptophan:fulvic ratios found in the Penrith Sandstone were found to be between $(0.5-3.0)$ and are characteristic of ratios from sheep waste sources. The Sherwood Sandstone has the lowest ratios $(0.2-0.4)$ indicating a different source of DOM, most likely a mixture of terrestrial and microbial sources, although there is little evidence of pollution from leaking urban sewage systems. Results from these two studies suggest that intrinsic fluorescence may be used as a proxy for, or complimentary tool to, other groundwater investigation methods in helping provide a conceptual model of groundwater flow and identifying different sources of DOM within the groundwater system.

\section{Keywords}

Dissolved organic matter (DOM), Fluorescence, Groundwater, Sources of organic carbon, Tracing groundwater flow

\section{Introduction}

Dissolved organic matter (DOM) is known to have a range of important functions in the aquatic environment as both a source of energy for micro-organisms and in its role in the transport of metals and organic contaminants (McKnight et al., 1992; Benedetti et al., 1996). The structure, composition and abundance of DOM in the environment controls many important transport processes. DOM includes chemically defined compounds such as carbohydrates and proteins, and humic substances which include fulvic and humic acids which are operationally defined based on their solubility (Thurman, 1985). Recent studies suggest that humic substances are a complex mixture of both microbial and plant biopolymers, with their various breakdown products, and cannot be classed as a distinct chemical structure (Kelleher and Simpson, 2006). In the natural environment DOM is often a complex mixture of many compounds and as such is difficult and costly to characterise (Leenheer and Croue, 2003). 
Dissolved organic carbon (DOC) concentrations in UK groundwaters have a large range (0.18-18.6 mg C/L, n=113) with mean concentration of 3.09 (Gooddy and Hinsby, 2008). This is a reflection of both the different sources of DOC and different aquifer properties. For example, TOC (total dissolved organic carbon) concentrations in two Permo-Triassic Sandstone aquifers have a broader range and generally higher TOC concentrations than Chalk aquifers in the UK and this could be due to the larger pore throat sizes found in sandstone systems (Bloomfield et al., 2001).

Natural organic matter (NOM) is derived from the decay of organic material from both plant, animal and microbial sources and a significant proportion of NOM fluoresces (Senesi, 1993). Fluorescence spectroscopy has been used in many studies to understand the source and composition of DOM in marine, wastewater, surface water, groundwater and terrestrial ecosystems (Coble, 1996; Sierra et al., 2001; McKnight et al., 2001; Reynolds and Ahmad, 1997; Holbrook et al., 2006; Baker, 2001a; Baker and Curry, 2004; Cannavo et al., 2004).

Recent studies have highlighted the use of fluorescence properties of DOM to discriminate between different sources of DOM, and as a natural tracer to understand water movement (Baker, 2001b; Hall et al., 2005; Mariot et al., 2007). The rapid collection of highresolution fluorescence data at multiple excitation-emission wavelengths is now common and has led to the use of excitation-emission matrices (EEMs) which represent the three dimensional fluorescence landscape of a particular sample. This method has the benefit of being rapid $(<2 \mathrm{~min})$, requiring low volumes $(<5 \mathrm{~mL})$ and is also non-destructive, these factors combined make it an ideal method for characterising DOM in natural waters.

Understanding the groundwater movement is essential for assessing the susceptibility of an aquifer system to contamination and also predicting how quickly any degradation in water quality may be reversed. A basic understanding of these processes is important in order to 
provide a framework within which chemical and microbiological transport processes can be better understood. Various hydrochemical tracers have been used to understand groundwater movement and sources including dissolved gasses, isotopes (stable, radiogenic and radioactive), dyes and bacteriophage (Manning and Caine, 2007; Harden et al., 2003). Groundwater concentrations of anthropogenic atmospheric trace gases such as chlorofluorocarbons (CFCs) have also been used to understand the dynamics of groundwater movement in the subsurface (Plummer et al., 2000; Szabo et al., 1996; Gooddy et al., 2006).

Previous studies at the Sherwood Sandstone sites have used microbial indicators, CFCs and carbon stable isotopes to understand the impact of urban drainage on the groundwater quality and flow regime (Cronin et al., 2006; Rueedi, et al., 2006; Morris et al., 2006). In this study we are therefore able to test the use of fluorescence analysis as a proxy for tracing groundwater mixing and recharge. Additionally, fluorescent spectroscopy might provide information about the different forms of organic matter emanating from the two landuse settings. Importantly, both sites had been previously instrumented for other hydrogeological investigations and a hydrogeological conceptual model already devised.

This paper outlines the use of fluorescence properties of DOM as a possible tracer for groundwater movement within two Permo-Triassic Sandstone aquifers and tests this hypothesis by comparing the technique with other established tracer methods; CFCs and microbiological indicators. It also investigates the potential of fluorescence analysis to "fingerprint" different sources of DOM at depth within the groundwater system. 


\section{Samples and Methods}

\subsection{Study sites}

Two study sites from the Permo-Triassic Sandstone were chosen for this study, one in the Penrith Sandstone of Cumbria (site A) and one in the Sherwood Sandstone of South Yorkshire (site B), see Figure 1. Both aquifers are regionally important sources of public water supply and have contrasting hydrogeological settings. At the Penrith Sandstone site, groundwater flow has been characterised by largely inter-granular flow (mean permeabilities of $0.8 \mathrm{~m} / \mathrm{d}$ ) based on regional models and pump test data (Allen et al., 1997). However, there are localised cases where fracture flow is important and where pumping test have derived hydraulic conductivities that are much higher (Price et. al., 1982). Both study sites have oxidising conditions based on DO, Eh and Fe concentrations, and therefore changes in fluorescence due to changing redox gradients (Klapper et al., 2002) within the groundwater system are not likely to be important.

Regionally the Sherwood Sandstone is considered highly anisotropic, and in Doncaster there is evidence of localised rapid routing to depth along fractures and marl bands, where local transmissivities of between $76-92 \mathrm{~m}^{2} / \mathrm{d}$ have been found (Morris et al., 2006). Site A is located within a rural agricultural landuse setting, while site B can be characterised as suburban, located within close proximity to the city centre. Figure 2 gives details of the conceptualised groundwater flow processes at both sites. The local groundwater flow direction for site A is SW-NE for site B it is W-E.

\subsection{Materials and methods}

Groundwater samples were taken from two locations at site A (EV2 and EV3) using packers to sample groundwater from discrete depths within the saturated zone. Three multilevel groundwater arrays were sampled at study site B (HP1, HP2 and BH). These are 
small bore monitoring wells with $0.3 \mathrm{~m}$ long screens set a specific depth intervals set within a thick (1-3m) bentonite clay seal. Samples were taken only after the system had been thoroughly purged by prolonged pumping.

Samples for fluorescence and DOC analysis were filtered using 0.45 micron silver filters and stored in the dark at $4^{\circ} \mathrm{C}$. Fluorescence analysis was carried out within a week of sampling, and usually within 48 hours. A Varian ${ }^{\mathrm{TM}}$ Cary Eclipse fluorescence spectrometer was used for the fluorescence analysis. Excitation (Ex) wavelengths were set between 200 and $400 \mathrm{~nm}$ with a $5 \mathrm{~nm}$ bandwidth and emission (Em) wavelength were set between 250 and $500 \mathrm{~nm}$ with a $2 \mathrm{~nm}$ bandwidth. The scan rate was $9600 \mathrm{~nm} / \mathrm{min}$ and the detector voltage was set to $900 \mathrm{~V}$, and all analysis was done in quartz vials with a path length of $1 \mathrm{~cm}$. All the samples had low DOC concentrations $(<5 \mathrm{mg} / \mathrm{L})$ and the fluorescence analysis was in the linear range for all components of the Ex/Em matrix, precluding the need for absorbance correction (Ohno, 2002). The Raman peak of water at $348 \mathrm{~nm}$ was used to check for instrument stability prior to analysis. Repeat sample analysis showed that the fluorescence intensity of the different components of the excitationemission matrix (EEM) had a relative standard deviation of $<5 \%$. Ultrapure water (ASTM type I reagent grade water, including a UV cracker) was used for the blank sample, to make up reagents and clean the quartz cell between samples. DOC analysis was carried out using a Thermalox ${ }^{\mathrm{TM}} \mathrm{C}$ analyser after acidification and sparging.

\subsection{Fluorescence data analysis}

Raman lines were removed by blank subtraction and Raleigh-Tyndall lines were masked out for data processing purposes by multiplying the sample matrix by a matrix of ' 0 's and '1's. Only fluorescence data above Ex250nm was used due to the instability in the region below Ex250nm. Inspection of the fluorescence EEMs revealed that there were up to four 
components in each EEM, two fulvic-like and two protein-like ( tyrosine and tryptophanlike components, although tyrosine-like components were not present in most samples). Tryptophan-like (TPH) intensities were reported as mean intensities from the following region Ex270nm, Em330nm-Em350nm and fulvic-like intensities (FA) were reported as mean intensities from the following region Ex330nm, Em410-440nm. Total fluorescence was determined by summing the intensity across the whole EEM after masking the Raman and Raleigh lines. Results for intensities are reported in arbitrary units (a.u). The ratio of the emission intensity at $450 \mathrm{~nm}$ and $500 \mathrm{~nm}$ at an excitation wavelength of $370 \mathrm{~nm}$ was used as a fluorescence index (FI) to investigate the source of the DOM (McKnight et al., 2001). The ratio of TPH to FA has also been used to identify different potential sources of DOM based on characteristic ratios found in different source terms (Baker, 2002). All the post processing of fluorescence data was carried out using the statistical package $R$ ( $R$ Development Core Team, 2008; Lapworth and Kinniburgh, submitted).

\section{Results}

\subsection{Depth profiling total fluorescence}

Figure 3 shows the changes in total fluorescence intensity with depth within the saturated zone for both sandstone aquifers. There are clear differences in the fluorescence profiles of both systems. In the Penrith Sandstone (Site A) there is a rapid decrease in fluorescence intensity at the top of the profile, after which intensities remain relatively constant down the profiles to a depth of 100 meters below ground level (mbgl). In the Sherwood Sandstone (Site B) the intensity drops within the top $20 \mathrm{mbgl}$, but then increases again at 40-60 mbgl. Overall, the intensities in the Sherwood Sandstone are much lower than those found in the Penrith Sandstone. There is a good correlation between FA intensity and DOC $\left(r^{2}\right.$ of $\left.0.58, p=0.05\right)$, as might be expected, given that a large proportion of dissolved 
organic matter fluoresces. It is also clear that while the majority of DOC within the profile is FA in nature, in some cases samples having identical DOC contents can have fluorescence intensities that varying by a factor of two within the same site.

\subsection{Depth profiling of fluorophores, CFCs and microbiological indicators}

The profiles for FA and TPH, the ratio of TPH:FA, CFC-12 and FI from the Penrith Sandstone sites are shown in Figure 4. The FA intensity decreased rapidly in the profile from EV2, and there are comparable intensities for both profiles at depth within the saturated zone. The TPH intensity also decreased with depth with overall slightly higher intensities in EV2 at depth. The CFC-12 profile emulates the FA profile, decreasing rapidly in concentration from the water table in EV2.

The average FI along the profile was 1.5. The FI decreased with depth from around 1.5, values consistent with terrestrial sources of DOM (McKnight et al., 2001), to 0.4 and then increased at around $70 \mathrm{mbgl}$ to higher values consistent with microbial sources (1.3-2.3). This also emulates the profile of the other tracers (CFC-12) and may indicate a more microbial source of DOC at this depth.

Figure 5 shows the profiles for FA, TPH, TPH:FA, number of microbes (faecal streptococci (FS) and sulphur reducing clostridia (SRC)), CFC-12 and FI for three multilevel sites in the Sherwood Sandstone. All three sites show an overall decrease in FA intensity down the profile from the water table to a depth of $35 \mathrm{mbgl}$. There is an increase in intensity at $35 \mathrm{mbgl}$ for the $\mathrm{BH}$ profile and an increase at $60 \mathrm{mbgl}$ for the other two HP profiles. This trend is also mirrored in the microbiology and the CFC-12 data for the different sites in the Sherwood Sandstone. The profiles for TPH also show the same trend, except at site HP2, which does not show an increase in TPH intensity at $60 \mathrm{mbgl}$. The TPH:FA profile is similar for all three sites with lowest ratios at the top and bottom of the 
profiles. The FI for all three sites does not vary much down the profile compared to the Penrith Sandstone site and has an average value of around 1.5, with around half of the samples indicating a predominantly terrestrial source of DOM. There are samples with values around 1.8 at the top and bottom of the profile which may indicate more microbial source of organic carbon. TPH signatures have a positive correlation with the CFC-12 $\left(\mathrm{r}^{2}=\right.$ $0.62, \mathrm{p}=0.05)$ and also shows a similar profile to the microbiological data. There is also a weak negative correlation between FA and TPH:FA for this site $\left(\mathrm{r}^{2}=0.36, \mathrm{p}=0.05\right)$.

There is a good positive correlation between FA-like intensity and CFC-12 for both aquifer types $\left(r^{2}\right.$ of $\left.0.73, p=0.05\right)$, although the majority of the data points for the Penrith Sandstone are clustered at low concentrations/intensities. Figure 6 shows a cross-plot of FA-like intensities against TPH:FA-like ratios for both sites. It can be seen that the two systems being studied have different characteristic signatures, with the Sherwood Sandstone system having much lower TPH:FA ratios compared to the Penrith Sandstone, suggesting different sources of DOM.

\section{Discussion}

The fluorescence results from the two study sites corroborate the hydrogeological models and understanding of groundwater flow already established by CFC and microbiological studies at site B (see Figure 2). The relatively high fulvic-like intensities in shallow groundwaters from terrestrial sources both in the shallow parts of the aquifer (5-20 mbgl) and at depth $(60 \mathrm{mbgl})$ reflect the relatively shallow groundwater table and zones of rapid routing along marl bands in the Sherwood Sandstone (Morris et al., 2006). Changes in pH and quenching from cations have been shown to effect the fluorescence intensity of different fluorophores (Lanne, 1982; Senesi, 1990; Patel-Sorrentino et al., 2002), however cation concentrations and $\mathrm{pH}$ do not vary significantly with depth at either study site ruling 
this out as an explanation for the fluorescence profiles found. Both sites can be considered oxic, based on DO, Eh and Fe concentrations, and the effects on the fluorescence of organic matter due to reducing redox conditions and redox gradients reported in other studies (Klapper et al., 2002, Cory and McKnight, 2005) are also not likely to be important at either site. While adsorption (Wang et al., 1997), and possibly microbial degradation processes, within the aquifers explain the overall decrease in organic carbon from terrestrial derived sources, and hence the decreases in FA intensities and total fluorescence, both systems have protein-like components which suggest additional sources of organic carbon at depth within the groundwater system.

\subsection{Penrith Sandstone (Site A)}

A rapid flow path of relatively modern organic carbon is needed to explain florescence profiles of these protein signatures and why there is a good correlation with terrestrial derived fulvic acids and CFCs. One possible source could be recent slurry applications from animal waste sources. This has been historically common practice in this area, which both improves soil fertility and facilitates the disposal of waste material from farms. From the CFC data at EV2 and fluorescence profile, a rapid flow route at depth is implied, located both in the shallow saturated zone and between 60-70 mbgl. The decrease in FI between $20-55 \mathrm{mbgl}$ (Figure 4) could be due to the increasingly recalcitrant nature of the fulvic acids with depth and adsorption processes associated with hydrous mineral oxides (Wang et al., 1997). There is a step change in the FI profile at $60 \mathrm{mbgl}$ which also corresponds with relatively higher CFC-12 concentrations possibly indicating a zone of fracture flow and a source of relatively young groundwater and relatively less recalcitrant DOM within this part of the profile.

The FI results from $60-70 \mathrm{~m}$ suggest a more microbial source of fulvic acids and are in contrast with the FI values between 30-60 mbgl which suggest a predominantly terrestrial 
source of DOM. A small component of relatively recent recharge from a slurry-derived source could explain both the fluorescence profiles and the CFC results.

Digital Optical Borehole Imaging System (DOBIS) scans from EV2 show the presence of a relatively large fracture at $67 \mathrm{mbgl}$ which corroborates the earlier suggestion of fracture flow in this section of the borehole, however the relatively low intensities found at depth imply only a minor impact on the water quality from relatively recent sources of DOM. No significant in-situ source of DOM at depth, such as buried peat lenses or bands rich in organic matter, were identified from a detailed examination of the DOBIS scans, suggesting that an in-situ sources of DOM was unlikely to explain the fluorescence profiles in the water samples.

The fluorescence and CFC profiles suggest that there are distinct regions within the borehole profile where more rapid flow is occurring under pumped conditions, both at the top of the profile and at depth within EV2 (60-70 mbgl). These findings suggest that there is potential for the rapid transport of relatively recent DOM from terrestrial sources to depth within the Penrith Sandstone. Macropore flow, which may by-pass and reduce the usual filtration, dilution and adsorption processes that happen during inter-granular flow, could have implications for water quality at depth. Previous work shows the importance of colloidal transport on organic pollutants in shallow UK aquifer systems (Gooddy et al., 2007) and similarly here, there is the potential for colloidal bound contaminants to travel faster and further through the aquifer system than regional flow models might predict (McCarthy and Zachara, 1989). While these rapid flow networks may be largely insignificant during steady-state conditions where matrix flow dominates, it may become more important under pumped conditions, particularly when an abstraction borehole intersects a fracture network. 


\subsection{Sherwood Sandstone (Site B)}

The increased TPH:FA in the middle section of the profiles (35-45 mbgl, see Figure 5) coincides with the zone of lower CFC-12 concentrations and lower FA intensities and suggests a different source of DOM in this section of the profile, possibly groundwater with a smaller component of rapid fracture flow and larger component of slower intergranular flow (see Figure 2). The higher TPH:FA ratio in this part of the profile may also suggest that the recent recharge from fracture flow at the top and bottom of the profile may be diluting any waster water signal from urban sources. These results corroborate the suggestion of Morris et al. (2006) that while there may be a small component of rapidly moving water at the top of the profile and reaching depths in excess of $60 \mathrm{mbgl}$, overall the aquifer system is not grossly polluted from urban waste water sources. The protein-like intensities and the FA-like intensities would be much higher if gross pollution was occurring directly from leaking urban sewage systems. The TPH:FA values are low $(<0.4)$ which also suggests that the groundwaters are not greatly impacted with organic matter derived from waste water sources (Barker et al., 2001a). The FI suggest that the DOM is from a mixture of both terrestrial and microbial sources, (McKnight et al., 2001).

Both FA and TPH show a good positive correlation with the CFC tracer and this suggest that within these systems fluorescence tracers may be used alongside or as a proxy for established recharge/tracer techniques.

The use of TPH:FA ratios shows that the two systems in this study have different characteristic signatures for DOM. The Sherwood Sandstone has the lowest ratios $(0.2-$ 0.4) indicating a different source of DOM (Figure 6), most likely a mixture of natural terrestrial sources with possibly a minor component of leakage from urban sewage systems. The TPH:FA ratios found in the Penrith Sandstone are higher (0.5-3.0) and are characteristic of ratios from sheep waste sources (Baker, 2002). 


\section{Conclusions}

The fluorescence technique has been shown to compare well with other tracer techniques in identifying rapid routing at depth at two study sites in the Permo-Triassic sandstone using both multi-level samplers and packers to sample groundwater from discrete depths within the saturated zone. At both sites FA intensities showed a good correlation with CFC-12, an atmospherically derived anthropogenic groundwater tracer. The fluorescence intensity profile in the Sherwood Sandstone showed TPH peaks at depths in excess of 50 metres and mirrors the pattern exhibited by microbial species (faecal Streptococci and S-R Clostridium) and CFC-12 highlighting the deep and rapid penetration of modern recharge. Results from these two studies demonstrate that the intrinsic fluorescence technique can be used as a proxy for, or complimentary tool to, other groundwater investigation methods in helping provide a conceptual model of groundwater movement. In addition it may be used to rapidly identify different types and relative abundances of DOM and fingerprint different sources of organic carbon within the groundwater system.

\section{Acknowledgments}

The authors acknowledge the contribution of S Hannay in carrying out chemical analysis and K Griffiths and M Cheetham for carrying out packer sampling. The authors would like to thank the reviewers for their comments on the original manuscript. This paper is published with the permission of the Executive Director, British Geological Survey (NERC). The authors would also like to thank the helpful review and comments from W.G. Darling.

\section{References}

Allen, D.J., Brewerton, L.J., Coleby, L.M., Gibbs, B.R., Lewis, M.A., Macdonanld, A.M., Wagstaff, S.J., Williams, A.T., 1997. The physical properties of major aquifers in England and Wales. British Geological Survey Technical report (WD/97/34). Environment Agency R\&D Publication 8, Keyworth UK. 
Baker, A., 2001a. Fluorescence excitation-emission matrix characterization of some sewage-impacted rivers. Environ. Sci. Technol. 35, 948-953.

Baker, A., Lamont-Black, J., 2001b. Fluorescence of dissolved organic matter as a natural tracer of ground water. Ground Water. 39, 745-750.

Baker, A., 2002. Fluorescence properties of some farm wastes: implications for water quality monitoring. Water Res. 36, 189-195.

Baker, A., Curry, M., 2004. Fluorescence of leachates from three contrasting landfills. Water Res. 38, 2605-2613.

Benedetti, M.F., Van Riemsdijk, W.H., Koopal, L.K., Kinniburgh, D.G., Gooddy, D.C., Milne, C.J., 1996. Metal ion binding by natural organic matter: From the model to the field. Geochim. Cosmochim. Acta. 60, 2503-2513.

Bloomfield, J.P., Gooddy, D.C., Bright, M.I., Williams, P.J., 2001. Pore-throat size distributions in Permo-Triassic sandstones from the United Kingdom and some implications for contaminant hydrogeology. Hydrogeol. Journal. 9, 219-230.

Butcher, A., Lawrence, A., Gallagher,A., Griffiths, K., Cheetham, M., Burke, S., Ingram, J., Merrin, P., 2008. Investigation of Rising Nitrate Concentrations in Groundwater in the Eden Valley, Cumbria: Saturated Zone Studies. British Geological Survey Technical Report, OR/08/024

Cannavo, P., Dudal, Y., Boudenne, J.L., Lafolie, F., 2004. Potential for fluorescence spectroscopy to assess the quality of the soil water extracted organic matter. Soil Sci. 169, 688-696.

Coble, P.G., 1996. Characterization of marine and terrestrial DOM in seawater using excitation-emission matrix spectroscopy. Mar. Chem. 51, 325-346.

Cory, R.M., McKnight, D.M., 2005. Fluorescence spectroscopy reveals ubiquitous presence of oxidised and reduced quinones in dissolved organic matter. Environ. Sci. Technol. 39, 8142-8149.

Cronin, A.A., Rueedi, J., Morris, B.L., 2006. The effectiveness of selected microbial and chemical indicators to detect sewer leakage impacts on urban groundwater quality. Water Sci. Technol. 54,145-52.

Gooddy, D.C., Darling, W.G., Abesser, C., Lapworth, D.J., 2006. Using chlorofluorocarbons (CFCs) and sulphur hexafluoride $\left(\mathrm{SF}_{6}\right)$ to characterise residence time and groundwater movement in a lowland Chalk catchment. Journal Hydrol. 330, 44-52.

Gooddy, D.C., Hinsby, K., 2008. Organic quality of groundwaters. In: Natural groundwater quality; Edmunds, W.M., Shand, P., Eds. Blackwell. ISBN: 978-1-40515675-2. pp59- 70

Gooddy, D.C., Mathias, S.A., Harrison. I., Lapworth, D.J and Kim, A.W., 2007. The significance of colloids in the transport of pesticides through Chalk. Science of the Total Environment. 385, 262-271.

Hall, G.J., Clow, K.E., Kenny, J.E., 2005. Estuarial fingerprinting through multidimensional fluorescence and multivariate analysis. Environ. Sci. Technol. 39, 75607567.

Harden, H.S., Chanton, J.P., Rose, J.B., John, D.E, Hooks, M.E., 2003. Comparison of sulfur hexafluoride, fluorescein and rhodamine dyes and the bacteriophage PRD-1 in tracing subsurface flow. Journal Hydrol. 277, 100-115. 
Holbrook, R.D.,Yen, J.H., Grizzard, T.J., 2006. Characterizing natural organic material from the Occoquan watershed (northern Verginia, US) using fluorescence spectroscopy and PARAFAC. Sci. Total Environ. 361, 249-266.

Kelleher, B.P., Simpson, A.J., 2006. Humic substances in soil: Are they really chemically distinct. Environ. Sci. Technol. 40, 4605-4611.

Klapper, L., McKnight, D.M, Fulton, J.R., Blunt-Harris, E.L., Nevin, K.P., Lovely, D.R., Hatcher, P.G., 2002. Fulvic acid oxidation state detection using fluorescence spectroscopy. Environ. Sci. Technol. 36, 3170-3175.

Lapworth, D.J and Kinniburgh, D.G., Submitted. An R script for visualising fluorescence excitation-emission matrices (EEMs).

Laane, R.W.P.M., 1982. Influence of $\mathrm{pH}$ on the fluorescence of dissolved organic matter. Mar. Chem. 11, 395-401.

Leenheer, J.A., Croue, J.P., 2003. Characterizing aquatic dissolved organic matter. Environ. Sci. Technol. 37, 18A-26A.

Manning, A.H., Caine, J.S., 2007. Groundwater noble gas, age, and temperature signatures in an Alpine watershed: Valuable tools in conceptual model development. Water Res.

Research. 43, W04404, doi:10.1029/2006WR005349.

Mariot, M., Dudal, Y., Furian, S., Sakamoto, A., Valles, V, Fort, M., Barbiero, L., 2007. Dissolved organic matter fluorescence as a water-flow tracer in the tropical wetland of Pantanal of Nhecolandia, Brazil. Sci. Total Environ. 388, 184-193.

Mc Carthy, J.F., Zachara, J.M., 1989. Subsurface transport of contaminants- mobile colloids in the subsurface environment may alter the transport of contaminants. Environ. Sci. Technol. 23, 496-502.

McKnight, D.M., Bencala, K.E., Zellweger, G.W., Alken, G.R., Feder, G.L., Thorn, K.A.,1992. Sorption of dissolved organic carbon by hydrous aluminium and iron oxides occurring at the confluence of Deer creek and the Snake river, Summit County, Colorado. Environ. Sci. Technol. 26, 1388-1396.

McKnight, D.M., Boyer, E.W., Westerhoff, P.K., Doran, P.T., Kulbe, T., Andersen, D.T., 2001. Spectrofluorometric characterisation of dissolved organic matter for indication of precursor organic material and aromaticity. Limnol.Oceanogr. 46,38-48.

Morris, B.L., Darling, W.G., Cronin, A.A., Rueedi, J., Whitehead, E.J., Gooddy, D.C., 2006. Assessing the impact of modern recharge on a sandstone aquifer beneath a suburb of Doncaster, UK. Hydrogeology Journal. 14, 979-997.

Ohno, T., 2002. Fluorescence inner-filtering correction for determining the humification index of dissolved organic matter. Environ. Sci. Tech. 36, 742-746.

Patel-Sorrentino, N., Mounier, S., Benaim, J.Y., 2002. Excitation-emission fluorescence matrix to study $\mathrm{pH}$ influences on organic matter fluorescence in the Amazon Basin Rivers. Water Res. 36, 2571-2581.

Plummer, L.N., Rupert, M.G., Busenberg, E., Schlosser, P., 2000. Age of irrigation water in ground water from the Eastern Snake River Plain Aquifer, south-central Idaho. Ground Water. 38, 264-83.

Price, M., Morris, B., Robertson, A., 1982. A Study of intergranular and fissure permeability in Chalk and Permian aquifers, using double-packer injection testing. Journal Hydrol. 54, 401-423. 
R Development Core Team. 2008. The R foundation for statistical computing, Vienna University of Technology, Vienna, Austria.

Reynolds, D.M., Ahmad, S.R., 1997. Rapid and direct determination of wastewater BOD values using a fluorescence technique. Water Res. 31, 2012-2018.

Rueedi, J., Cronin, A.A., Taylor, R.G., Morris, B.L., 2006. Tracing sources of carbon in

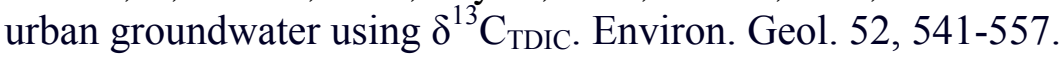

Senesi, N., 1990. Molecular and quantitative aspects of the chemistry of fulvic acids and its interactions with metal ions and organic chemicals. Part II. The fluorescence spectroscopy approach. Anal. Chim. Acta. 232, 77-106.

Senesi, N., 1993. In: Organic substances in soil and water: natural constituents and their influences on contaminant behaviour; Bech, A.J., Jones, K.C., Hayes, M.B.H., Mingelgrin, U., Eds.; The Royal Society of Chemistry: Cambridge, p 74.

Sierra, M.M.D., Donard, O.F.X., Etcheber, H., Soriano-Sierra, E.J., Ewald, M., 2001. Fluorescence and DOC contents of pore waters from coastal and deep-sea sediments in the Gulf of Biscay. Org. Geochem. 32, 1319-1328.

Szabo, Z., Rice, D.E., Plummer, L.N., Busenberg, E., Drenkard, S., Schlosser, P., 1996. Age dating of shallow groundwater with chlorofluorocarbons, tritium/helium 3, and flow path analysis, southern New Jersey coastal plain. Water Res. Research. 32,1023-1038

Thurman, E.M., 1985. Organic geochemistry of natural waters. Martinus Nijhoff/Dr. W Junk Publishers, Boston.

Wang, L., Chin, Y.P., Traina, S.J., 1997. Adsorption of polymaleic acid and an aquatic fulvic acid by goethite. Geochim. Cosmochim. Acta. 61, 5313-5324.

\section{Figures}

Figure 1. Sample site locations, Penrith Sandstone (site A) and Sherwood Sandstone (site B)

Figure 2. Conceptual hydrogeological flow regimes (adapted from Morris et al., 2006 and Butcher et al., 2008)

Figure 3. Changes in total fluorescence with depth

Figure 4. Depth profiles of fluorphores and CFC tracers in the Penrith Sandstone a) Fulvic acid, b) Tryptophan, c) Tryptophan: Fulvic acid ratio, d) CFC-12, e) Fluorescence index, $\mathrm{rwl}=$ rest water level.

Figure 5. Depth profiles of fluorphores, CFC tracers and microbes in the Sherwood Sandstone a) Fulvic acid, b) Tryptophan, c) Tryptophan: Fulvic acid ratio, d) CFC-12, e) Fluorescence index, f) Faecal Streptococci and S-R Clostridium. CFC-12 and microbe counts data from Morris et al. (2006), rwl = rest water level.

Figure 6. Cross-plot of tryptophan: fulvic acid ratio against fulvic acid intensity 